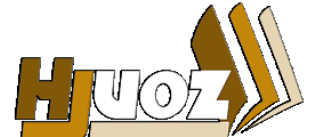

hjuoz.uoz.edu.krd p-ISSN: 2664-4673

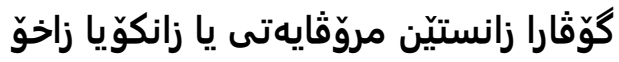

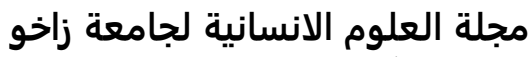

Humanities Journal of University of Zakho (HJUOZ)

Vol. 8, No. 4, pp. 558-565, December -2020

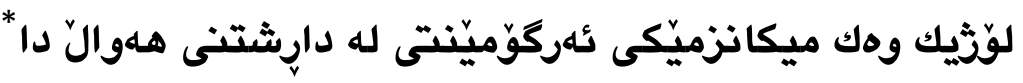 \\ بههار زاير محمد *1. و عبدلواحد مشير دزهيى 2
}

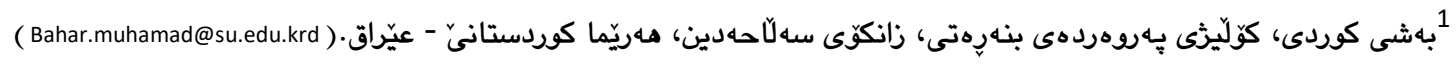

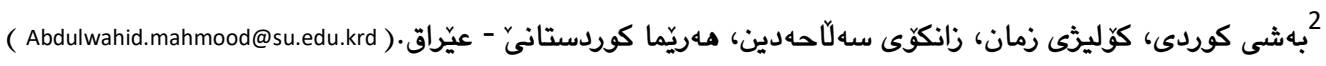

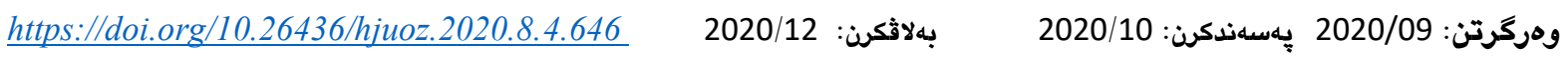

يَّْخته:

سهرهتا ئهركوّمينتى لوَّيكى، ئهو ميكانزمهيه كه نيّرهر دهيكريته بهر بوّ كاريكهرى دروست كردن لهسهر وهكر، بِهيوهسته بهو

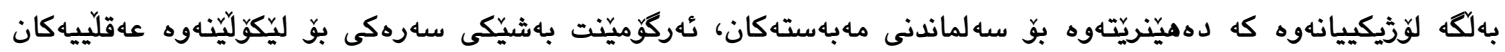

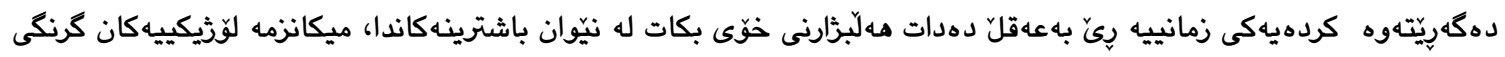

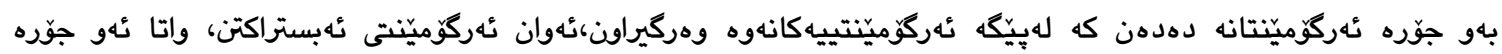

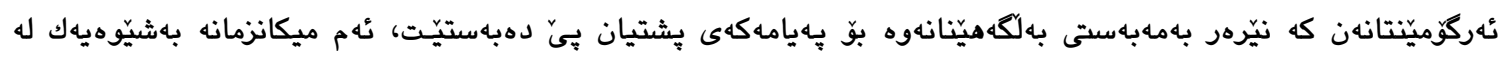

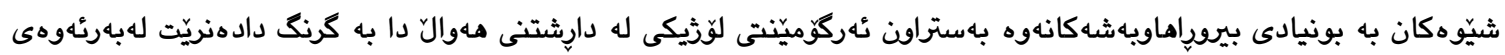

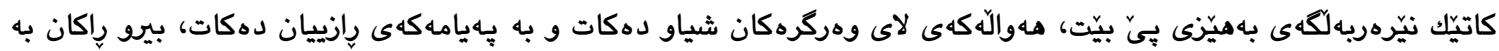

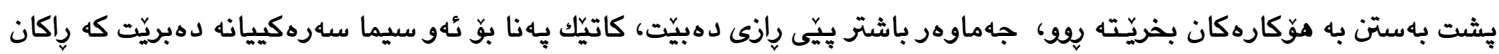
للهسهرى كؤكن ئهو كات لاى جهماوهر شياو تر دهبيّ.

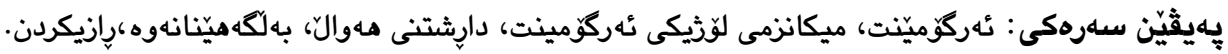

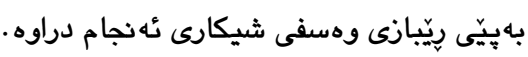
كرفتى تويَرينهوهكه:

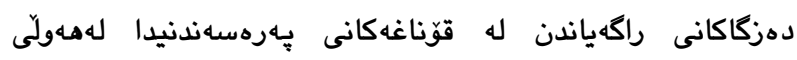

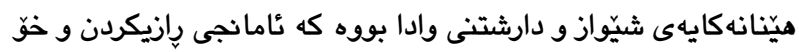
بهدهستوهدانى وهركر بيّكيت و كاريكهرى لهسهرى دروستكات،

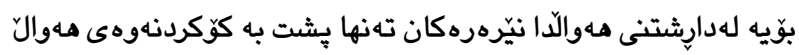

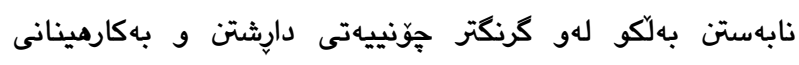
ميكانزمه كانى رإزيكردن، بهههند وهركيراوه، ئهمه ش بيّى دهوتريّيت ( هونهرى كهياندنى هدوالّ)، زّرجار خوّمان له بهرامبهر دوو جوره

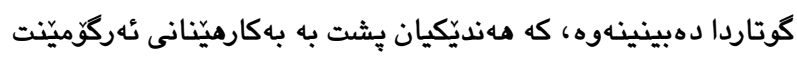

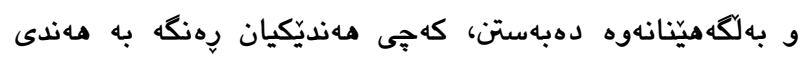
وهرنه كرن، بحّ كومان كوتارى سهركهوتو ئهو كوتارهيه تهنها زانيارى

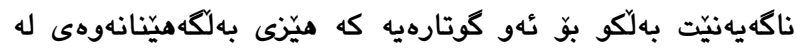

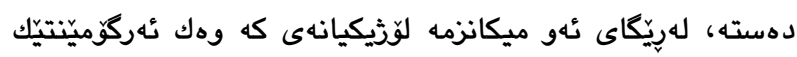

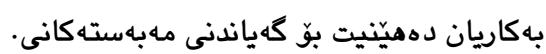

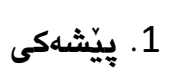

سنوورى تويَزَينهاوهكه :

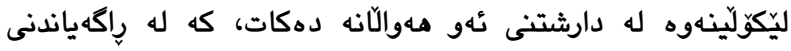

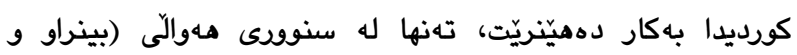
ئهليكتوزنى) دايه، به دياليّكتى ستانداردى ناوهراست. ئامانجى تويَّينهوهكه: دياريكردنى ئهو هاوالاّنهى كه له داريتنهكانيان، لوزّيكيان وهك

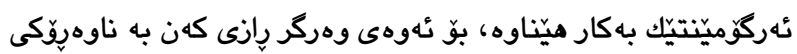
هـوالذكانيان. كرنغى تويزيزهوهكه :

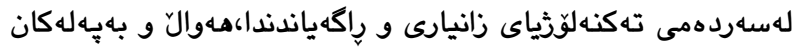

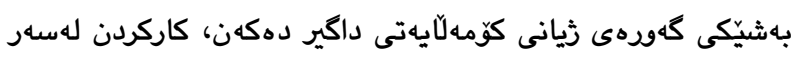

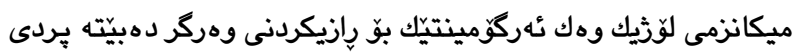
يهيوهندى بِّ بهرههم ميّنانى واتاى ماويه. ريّيازى تويَرَينهوهكه: 
La Grande Robert dictionaire langue: 1989:535) )

له فهرههنگى (كامبرج) به واتاى (بهلكه هينانهوهو پِاساو هيّنانهوه بو بشت راست كردنهوه يان درايهتى كردنى بيروّكهيهى ديارى كراو)

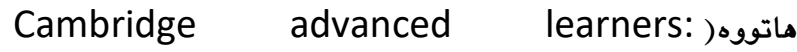
dictionary : 2004 P56) ئبن مهنزود له فهرههنگى (لسان العرب) ئامازهى به (الحجاج) كردووه بهوهى (تئهركوّمينت سه لماندنه، بهرامبهرهكهتى يَّ رإزى دهكهيت،

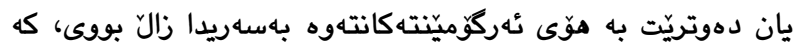

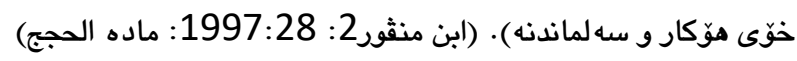

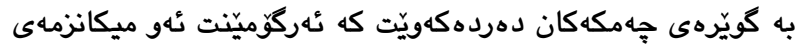
دركاندنه، كه نيّرهر دهيكريته بهر بهمهبهاستى دإزى كردن و كاريكهرى دهري

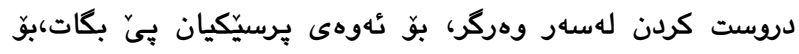

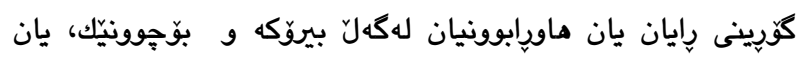

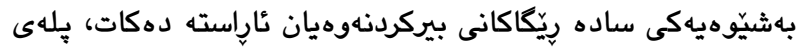

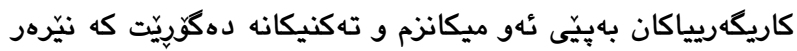
يـهنايان بوّ دهبات.

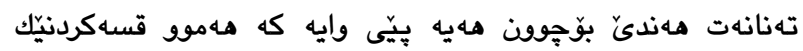

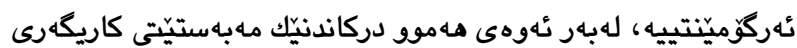
لهسهر بهرامبهرهكهى دروست بكات، يان شيّوهى بيركردنهوهى

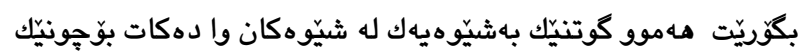
يان كردهيهك يان ديديّك بخولقينّيَت. (مشبال: محمد:2016:59)

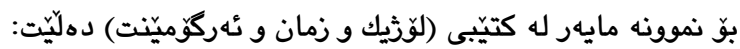

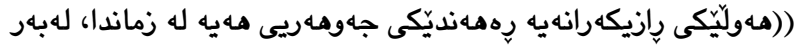
ئهوهى ههموو كوتاريك مهولَى ئهوه دهدات كه وهركرهكهى رإزاى بكات و كاريگهرى لهسهرى دروست بكات)) (ماير،ميشيل: 2010:

له لايهكى ترهوه ، وهك بهشيك له واتاسازى و بهكارهينانى زمان خرايه يوقو، بهلّام به شيوهيهك كه باسى ئهركوّمينت دهكريّت لهم

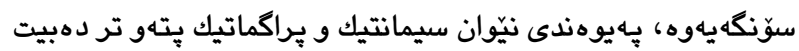

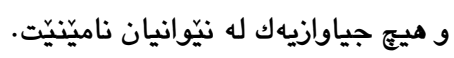

لهبهر نَهوهى زمان له خودى خوّيدا وهركيّرانى واقعه له سياقى

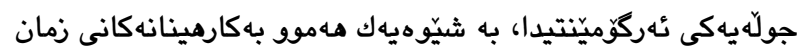

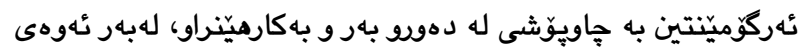

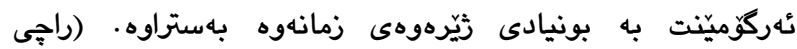
رشيد:2011: 195) بكومينت لهم يوهوه (ديكرو و ئهنسكوّمبهر) له كتيّبى (ئهركؤميّنت له نيّو

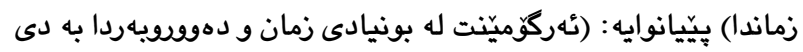

دهكريت). ( عزاوى،ابويكر: 2006: 58)
بوّ ديارى كردنى ئهم كرفتانه تويزَينهوهكه ئهم پِرسيارانه

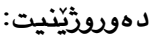

ا-بوّجى بوونى ئه ميكانزمه له كوتارى رِاگه ياندن و داريشتى هـوالّ

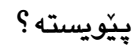

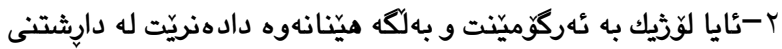
هـهوالدا؟

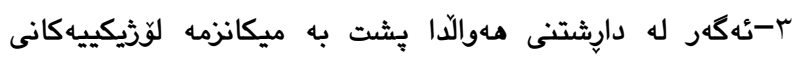

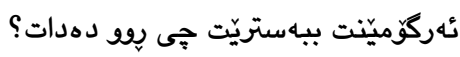

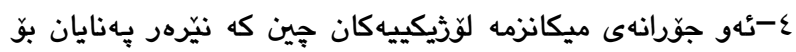
دهبات بوّ دارثشتنى هـوالَ دا ؟ كريمانه تويَّرينهوه كه : له م ليكولَيْهوهيهدا كريمانهى ئهوه دهوكهين كه :

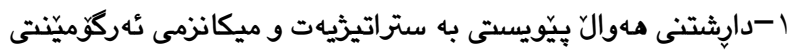

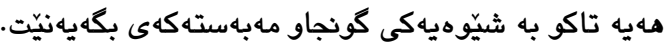

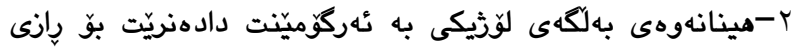
كردنى وهركر. ץ-له دارشتنى مدوالدا، ميكانزمه لوَزيكييهكان، دهبن به بهلكهى

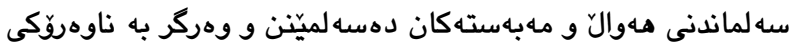

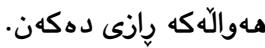

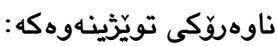

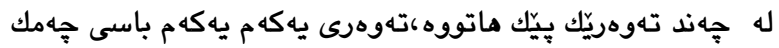

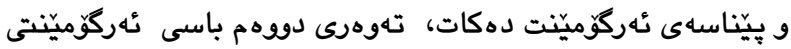
لؤزيكى دهكات له دارثتنى هدوالدا، پِاشان له تهوهى سيّيهم له

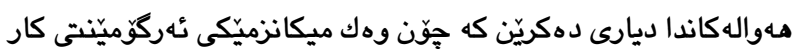

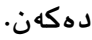

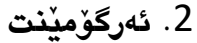

جهمكى Argument له جاوگى لاتينى Arguer وهر گيراوه، واتا

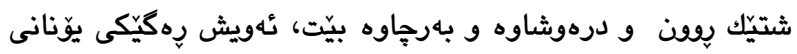

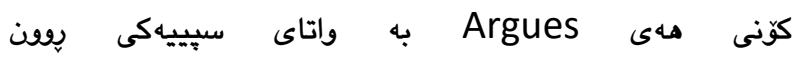

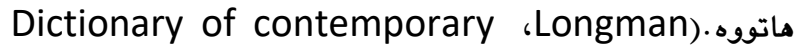
English (argue) part له زمانى ئينگليزى Argue به واتاى ئهوه ديّت كه كهيّك بيهوى

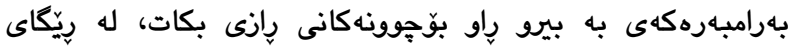

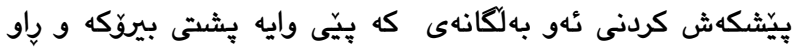

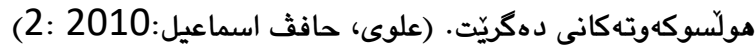

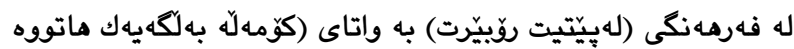
كه مهبهستى بهدهست هاتنى ئهنجاميّكى ديارى كراوه) واتا ئهركوّمينت و بهلكهكان بو دهست خستنى نئهنجاميّكى ديارى كراو 
بوّ ئهوهى وهركر رإزى بكات به راستى پِهيامه كهى و وايى ليّبكات بِيواى يَّ بهينيّنت.

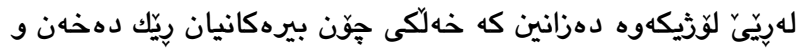

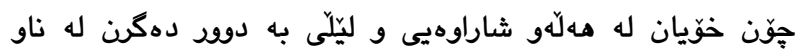

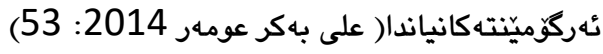

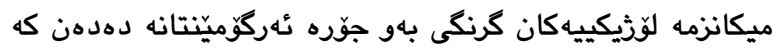

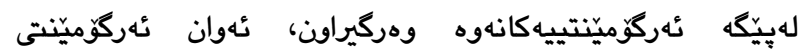

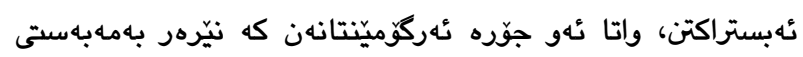

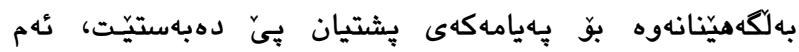

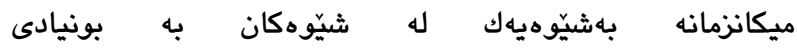

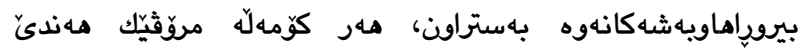

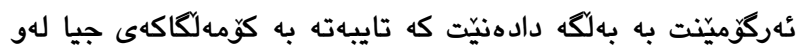

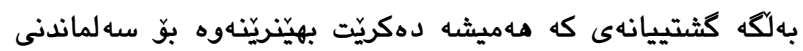

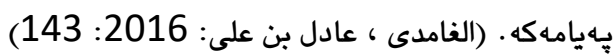

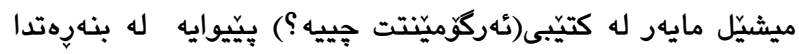

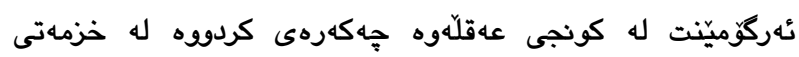
دابووه، ياشان فهلسهفه و زانست بهكاريان هيّناوه بو خوّيان، ئهوى يهكهم لهسهر شيّوهى (لؤزيكى ويّنهيى) و ئهوهى دووهم كراسيّكى ماتماتيكى وثكى بهبهردا كردووه. (الملوك، عبدالقادر : 2018:

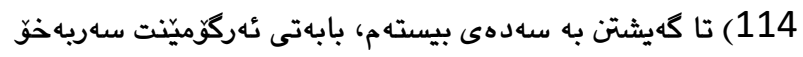
بوو، بهو يِيّيهى هـموو كوتاريّك به يلهى يهكهم كوتاريّكى نيّوان

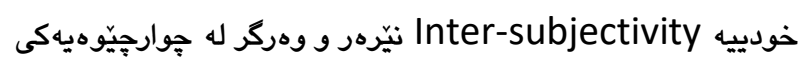
كارليّككردندان (واقعى يان كريمانهيى) بيّت، لهبهر ئهوهى هـر

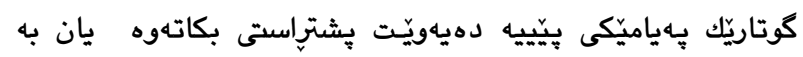

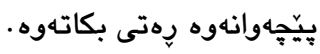

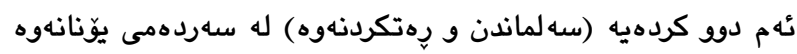

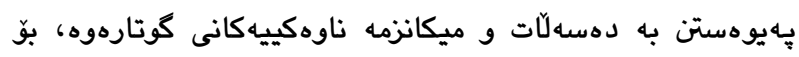
ئهوهى رازييوون بيّته نئهنجام.

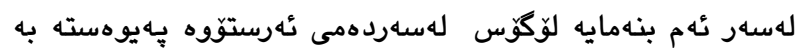

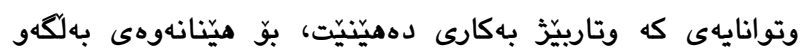

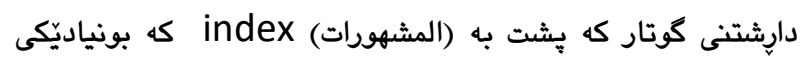

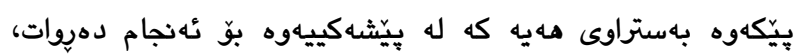

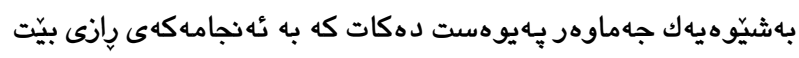
و نئهو رِيَكايانه بكريّت كه تانه لهو بئهركوّمينتانه بدات و لاوازى بكات.

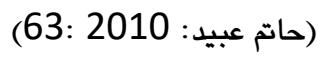
ئهركوّمينت ئامانجييهتى لهيهك كاتدا، كردهيهكى عهقلّى و هيزيّكى كاريكهربيّ، بهلام جياوازى نيّوان ئهم دوو كردهيه بهشيّوهيهكى

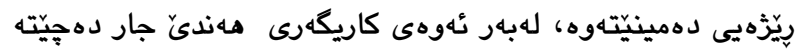

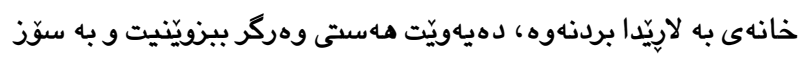

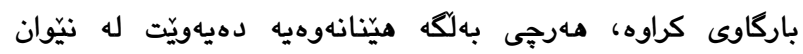

مهندىّ جاريش بهستراوهتهوه به يِراخماتيك و دهورو بهرهوه، به

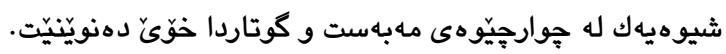

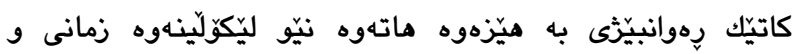
نازمانييهكان، ئهركّوميّت به بهشيّكى سهرهكى بابهتهكه دانرا و

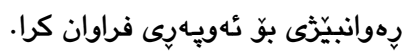

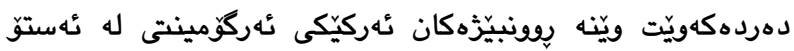
دهكرن و دهبن به رِيّازيكّ بو كهيشتن به راستييهكى جيّكير(دزهيى

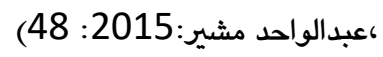

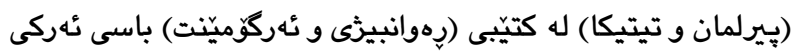
رهوانبيّزَى و ئهركوّميّنت دهكهن بهوهى: (( ئهو ميكانزمهى كوتارن كه وا له وهركر دهكهن زياتر بيوات يَى بكات، يان يِلهى ئهو بِيوا

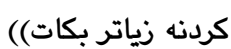
Perlman and tyteca:2008:9-10)) ئهم ئهركه ش دابه ش دهكهن بو سيّ به ش: ( مهكان سهرجهاوه: 26)

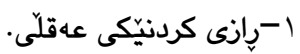

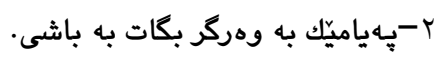
r- كردهيهك ئهنجام بدريّت.

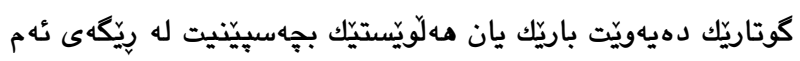
ميكانزمانهوه، كاريكهَرى دروست دهكات،و نامانجه كانى دهيِّكيّت.

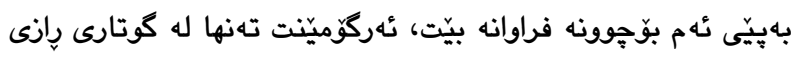

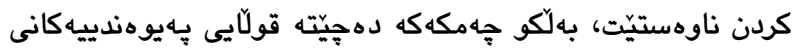

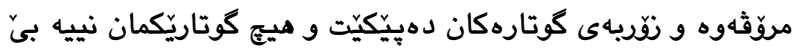

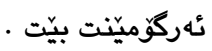

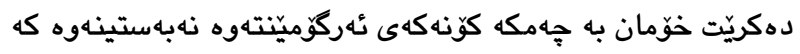
تهنها مهبه ستى رِازى كردنيّكى رِاستهوخو بيّت، بهلَّكو ميكانزمهكانى

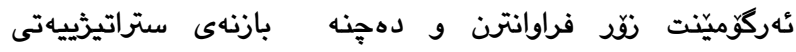

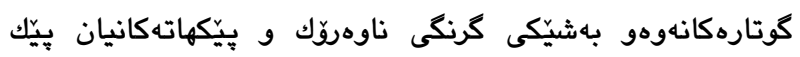
دهمينن. كوتارى رإكهياندنيش وهك مهدر كوتاريّكى تر له داريتنى هـوالَكانيدا

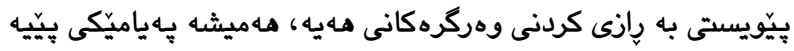

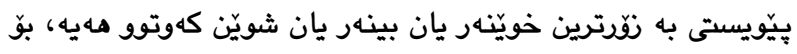

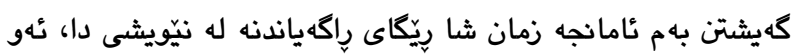
ميكانزم و ستراتيزيهتانهى كه وهركر رازى دهكات به پِهيامه كهى له

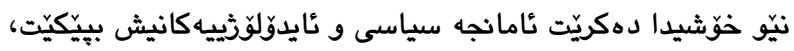

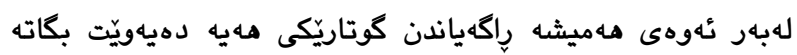
وهركرهكانى

\section{3. ميكانزمه لوَزيكييهكان}

ئهو ميكانزم و تهكنيكه عهقلِيّانه دهكريتهوه كه نيّرهر بهكارى

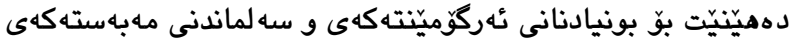


جهند شيّوهيهك وهركيراوه:

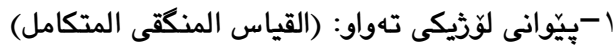

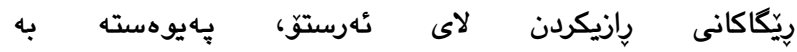

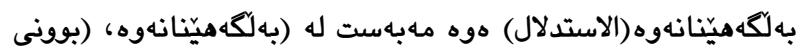

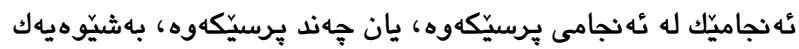

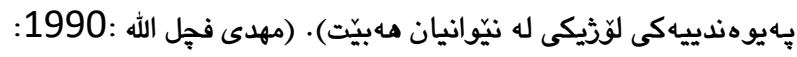

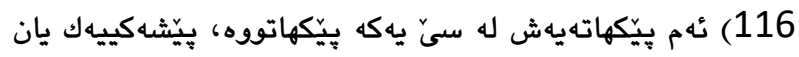

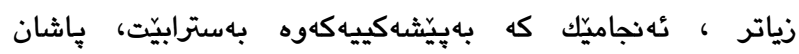
هـهيوهندييهكى لوَزيكى كه ئهمانه بهيهكهوه ببهستيّت .(بريوانه، ارسكو، الخكابه: 1986 154-155)

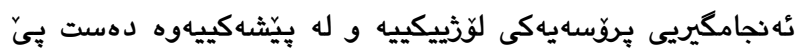

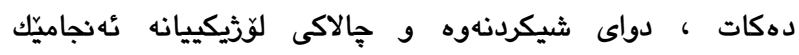
دهكهويتهوه، كه بهناجارى لهو يِيّشه كييه كهوتوّتهوه، تئهو نموونهيهى تئه رستو به كارى هيّناوه : سوكرات مروّقه مههوو مروّثيّك دهمريّت كهواته سوكرات دهمريّت

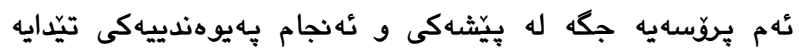
لايهنكان بهيهكهوه دهبهستيّهوه، نئهو پِهيوهندييه ناجارييه له

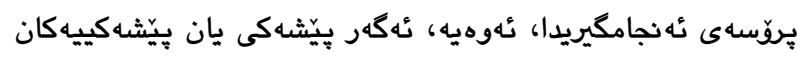

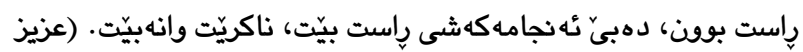

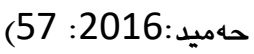

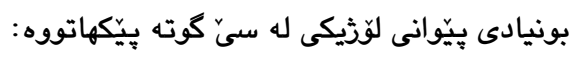

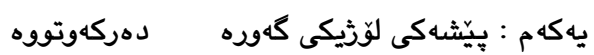

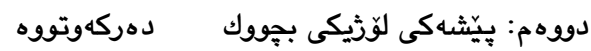

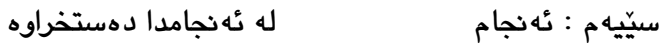

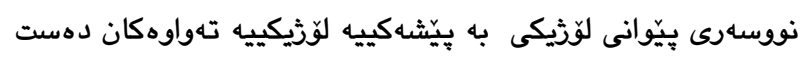

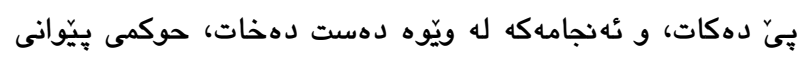

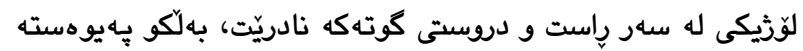
به يهايوهنى نيّوان كوتهكانهوه نايا ئهم كوتانه تهواون يان نا.

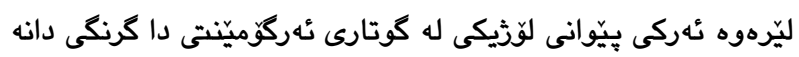

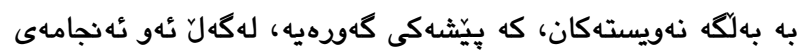

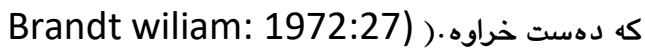
له وتوو ويّزيكدا له كهل دهنگى ئهمريكا ، ريّيوار كهريم محمدود

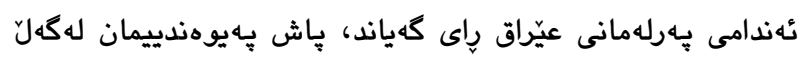

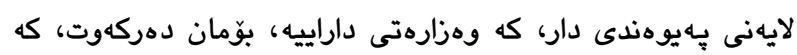

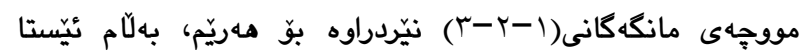

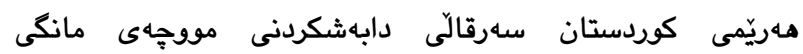
يهكه،كهواته كوا مووجه كانى مانكى يهكو دوو، بوّيه ئهو بابهته بهور

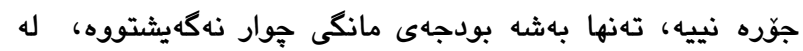

يُرسه كان پِهيوهندى دروست بكات و لايهنى مه عريفى فراوان دهكات.

(كروس محمد:2005: 89)

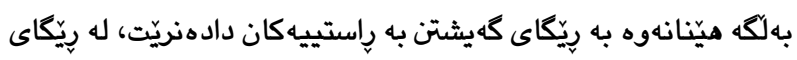

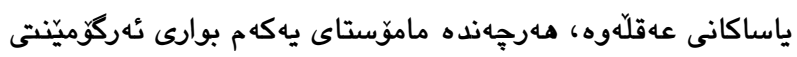

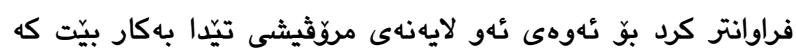

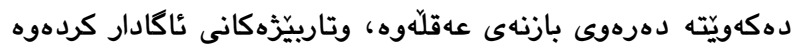

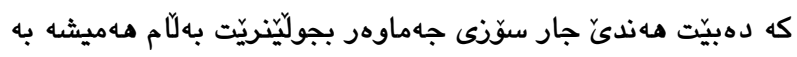

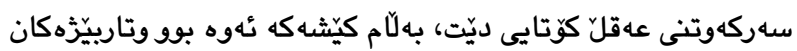

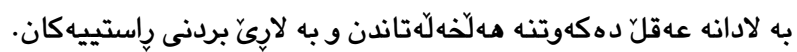

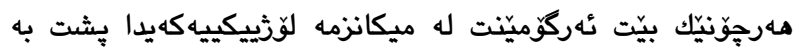
بهالكه مينانهوه عه قلّييهكان دهبهستيّت. 4. بهكارهيّنانى ميكانزمه لوَّيكييهكان له دارِشتنى هلوالّدا له داريشتى ههوالذا كاتيكّ رإستييهكان به بهلكه هينانهوه بسه لمينزرينّ، ئهوكات وهركر بيرى ليّ دهكاتهوه، بيرو رإكان به يشت

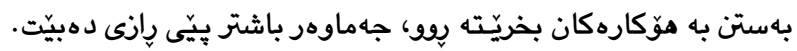

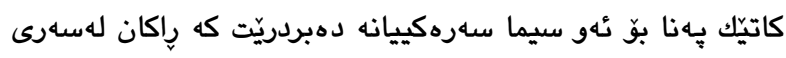
كوكن، ئهو كات لاى جهماوهر مهقبول تر دهبيّت. ( الملوك ،عبدالقادر:2014 : 119) دهزكاكانى راخهياندن هشت به بهم كاره

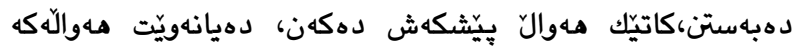
له سهر شيّوهى راستى دهركهويّت، بهشيّوهيهك ههموو توانا لوّجيستى و تهكنهلوزيييه كان دهخهنه خزمه تى ئه م بوارهوه، مه روهك (جاميت و و جانيّت) ( لناويان نا (جوراوجوّرهكان) كه له

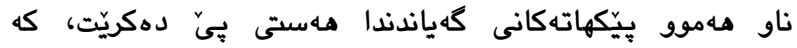
بهشيّوهيهك يـهيماننامهى گهياندن دروست دهكات له نيّوان تاكهكاندا

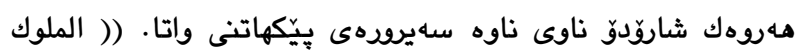

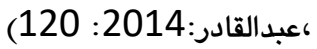
ئهكهر هـر هدواليّلك به نموونه وهركرين ، مهميشه له مدهلّى ئهوهدايه

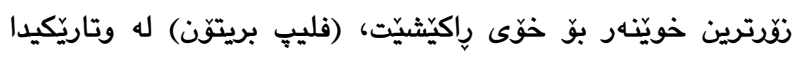

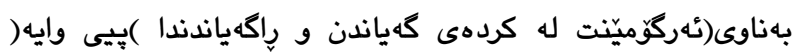
تاقيكردنهوهكه بهم شيّوهى دهست يَّ دهكات كاتيّك خويّنهـ رِستهى يهكهم دهخوينيّتهوه ، خوّى له نيّو مهلَبَراردنيّكى ديارى كراودا دهبينيّهوه، ئايا بهردهوام بيّت له خوينّدنهوهى؟ بوَيهدهبيّت

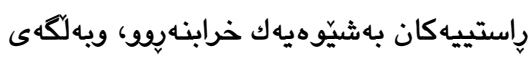
وا هينرابنهوه بهردهوامى به خويّندنهوهى ببهخشيّت). (ههمان

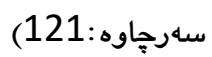
بهكورتى دهكريّت بوتريّت كه كوتارى راخهياندن، نيازى رِازيكردنى وهركرهكانى مهيه، ئهو كاته يِيّويستى به جههندين ميكانزمى جوّراو

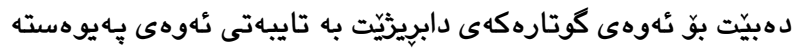

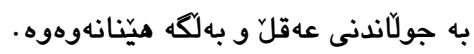




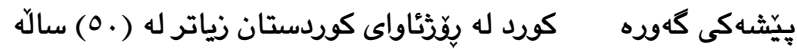
خهبات دهكهن.

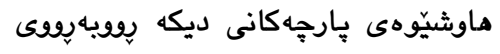

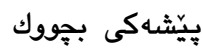
جهووسانهوهو سهركوتكردن بونهاتهوه. توانيويانه سوّزى كوّمهلكَاى نيّو دهولّهتى بوّخوّيان ئهنجام راكيّن. ئه گهر وشهكان به يـهيوهندى رِاسته خوّ به يهكهوه بهسترابوون ئهوا

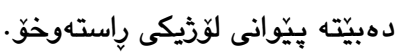
r-بِيَوانى لوَزيكى ناتهواو: (القياس المجِمر):

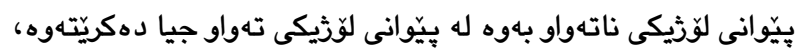

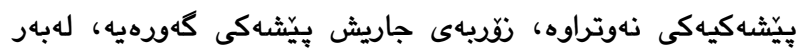

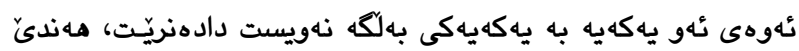

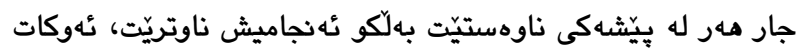

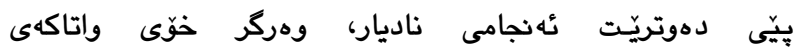

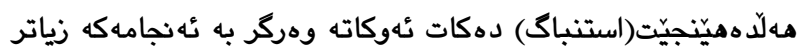
رإزى دهبيّت و كاريكهرييهكهى لهسهرى نْرتر دهبيّت، لهبهر نئوهى

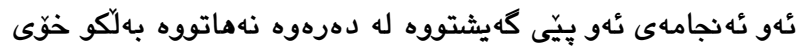
يّيّى كهيشتووه. (صوله ،عبد الله: 1991: 203) بهم شيّوهيه ميكانزمه لوَزيكييهكه بهميَز تر دهبيّت، وهركر لهكهل

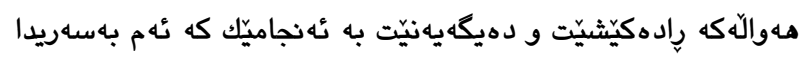

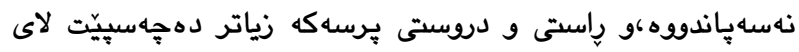

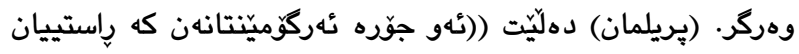

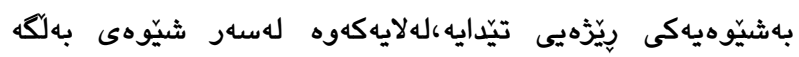

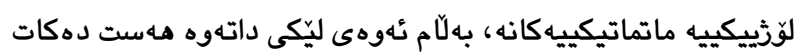
كه له كهل لوَزيكى ويّنهييدا جياوازى ههيه،لهبهر ئهوهى بِيّويستى به

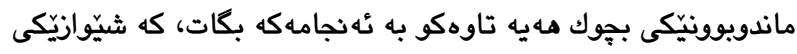

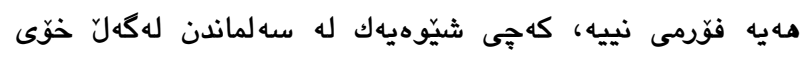

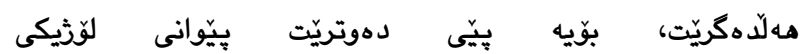
Perlman and tyteca:2008:194 (ناتهواو)(بونيك) سهروّكى نُهنجوومهنى پِهيوهندييهكانى دهرهوهى نئهريكا: ناوجهـكه

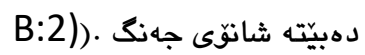
وهركرهكان تيّدهكَن، به بِيّى ئهو بِهيوهندييهى كه له نيّوان خوّيان

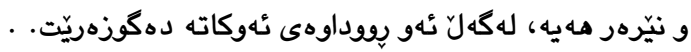

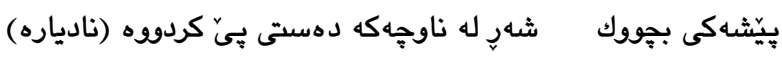

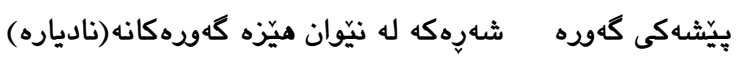

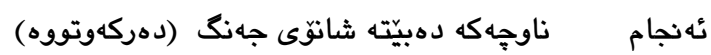
ليَرهدا تهنها ئهنجام دهركهوتووه، وهركر خوّى به بِيَشهييهكاندا تيَّيه بِيوه.

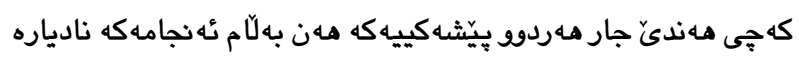

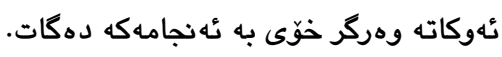

كاتيَكدا هـريّم هيّشتا مووجهـى مانكى يهكى نهداوه، نهخيّر هـريَم،

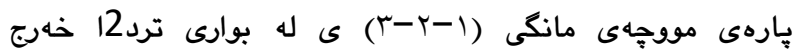

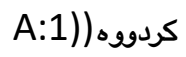
مووجهـى مانكهانى (ا-r-r-r) نيّردراوه بّو

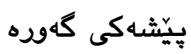
هـريّم

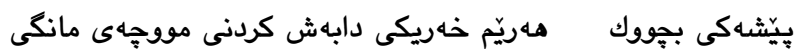
يهكه

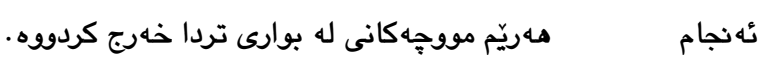

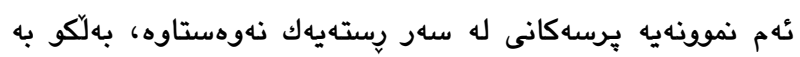

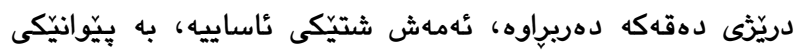

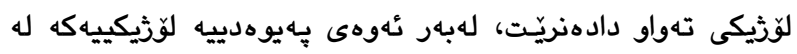
"ِيّكهاتهكانى مهيه. (محمد عكا الله: 2011-2012 : 65) پِهرلهمانى عيّراق به نِّرينهى دهنگ داواى كرد، حكوومهتى عيّراق

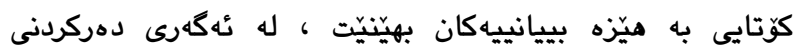
هيّزهكانى ئهمريكا له عيّراق ، ئهمريكا سزاى ئابوودى بهسهر عيّراقدا

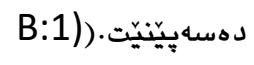

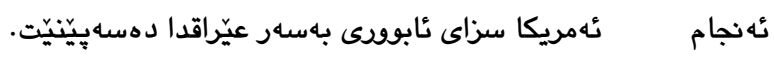

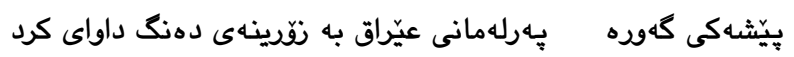
حكوومهتى عيّراق كوَتايى به هيّزه بييانييهكان بهينيّيت

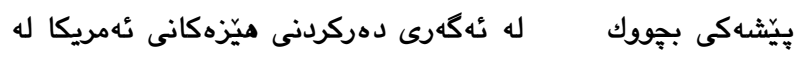
عيّراق بنهارهتى يِيّوانهكه بهم شيّوهيه:

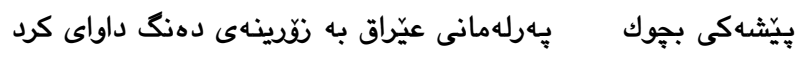

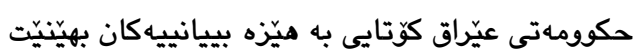

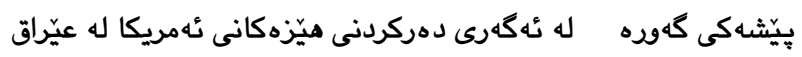

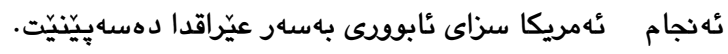

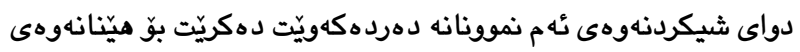

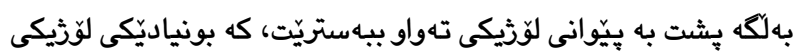
واتايى كرنكه له داريشتى هـوالَّا، شتيّكى ئاساييه كه هـوالَ داريّزَهر

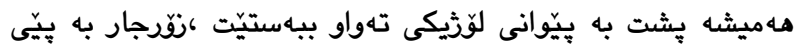

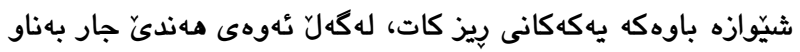
دهقهكدا يهكهكانى دابه ده دهبن، بهلّام ئهوكاته دهبيّت وهركر ماندووتر بيّت بوّ ئهوهى پِهويهندى نيّوان يهكهكان بدوَزيِتهوهو بهيهكيانهوه كريَّ بدات. كورد له يَّذئاواى كوردستان زياتر له (.0) سالَ خهباتى سياسى

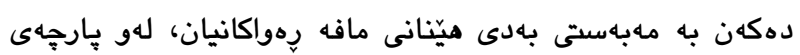

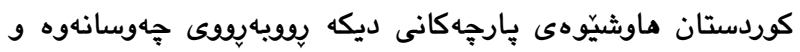

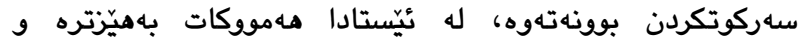

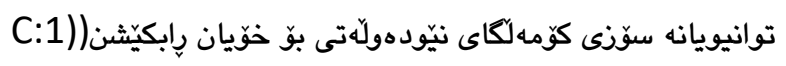


بيرلمان كردوييهتى بهسي بهشهوه ( prlman and L.o. tyteca:2008:94) 1-ئهو ئهركوّمينتانهى دوو بودوداو بهيهكهوه دهبهستيتهوه كه له دواى يهك هاتوون، لهبه هوَكاريّلك. جهواد زهريف: ئهمريكا هوّكارى خستنه خوارهوهى فرِّكهكهيه جونكه سهرى ليَّ شيّواندين (

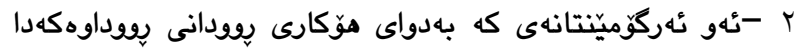

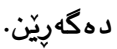

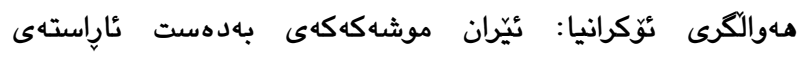

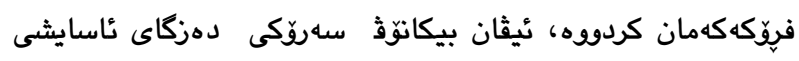

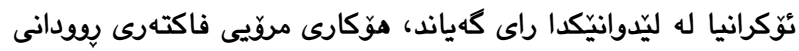
ئهو كارهساته بوو، بهكار خستنى سيستمى دزه مووشهكيش به بهان

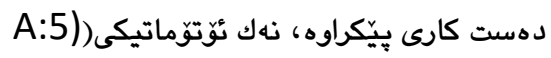

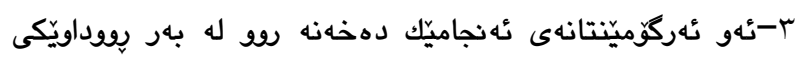
ديارى كراو. نيّرهر وهسفيّكى بابهتى پֶرسهكه دهكات، پֶاشان به شيكردنهوهو

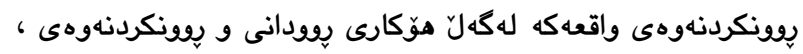

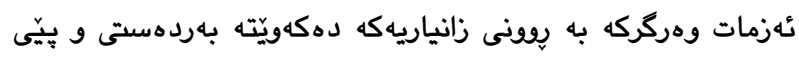

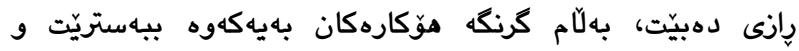

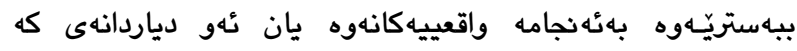

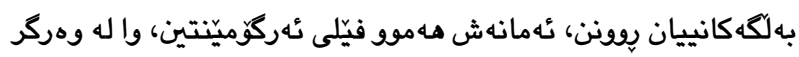
دهكات خوّى بهدهستهوه بدات.

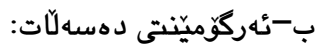

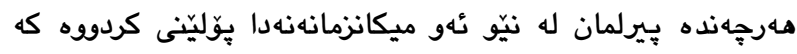

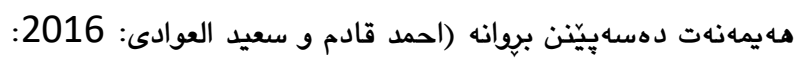

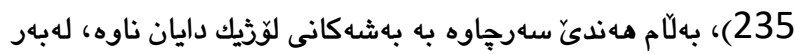
ئهوهى وهركر خوّى به شياو نازانيّت تانه لهو شتانه بكريت و رِنتيان كاتهوه و بوونهته بهشيّك له بهلكه نهويستهكان كهله دهسها لآتيكى

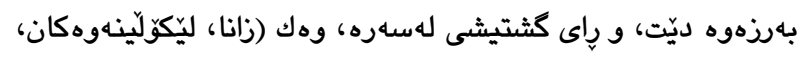

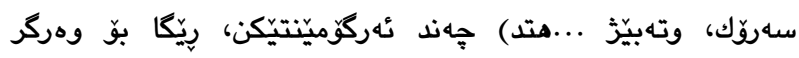

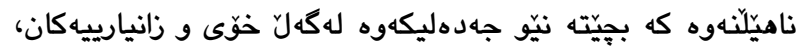
بهلكو بِيّى رِازى دهبيّت و خوّى بهدهستييهوه دهدات. (الغامدى

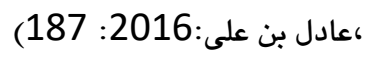

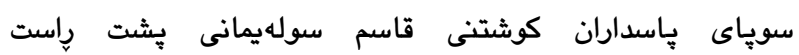
كردهوه. (B:5)

مهسرود بارزانى: فهرمان بهرى حكوومهت دهبيّت مهمنون بيّ خهلّك

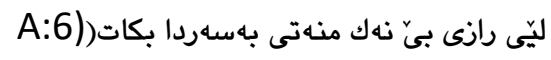

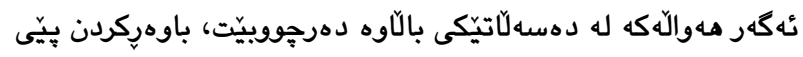
نقوتر دهبيّت و به بهشيّك له بهلكه نهويستهكان دهرميّردريّت.
ترهمب له كورد نيكهرانه، لهبهر ئهوهى له جهنگى جيهانى دووهم و

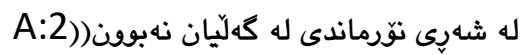

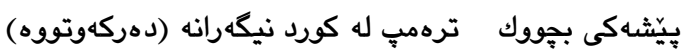

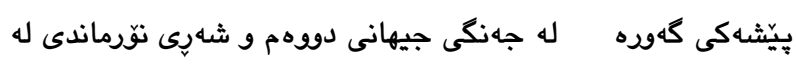
كهلّيان نهبوون (دهركهوتووه) ئهنجام لهم شهاره يارمهتييان نادات. (نادياره)

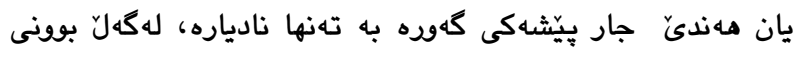

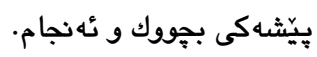

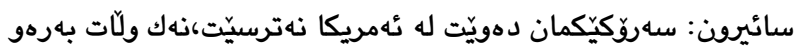
ويَرانى بيات. (B:3)

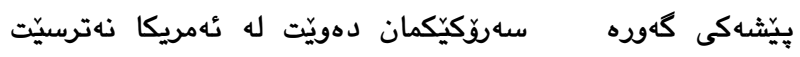

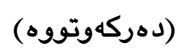

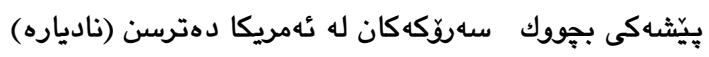
ئهنجام ولّات بهرهو ويّرانى ببات (دهركهوتووه)

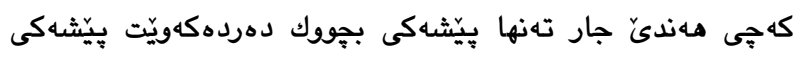
كهورهو ئه نجام ناديار دهبن. مهسرو بارزانى: حكومهت بهرامبهر بهزيان و كوزهرانى ئهو كهسانه ش بهريرسه كه دهنكدهرى هيج حزبيّك نين (A:3) پِيشهكى بجووك حكومهت بهرامبهر بهزيان و كوزهرانى ئهو

كهانهش بهريرسه كه دهنكدهرى هيج حزبيّك نين (دهركهوتووه) يّيشهكى كهوره حكومهت بهريرسه له زيان و كوزهرانى ههموو كه سيّك (دهرنه كهوتووه)

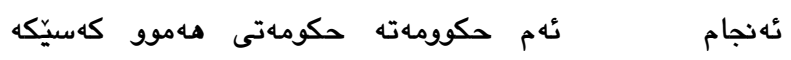

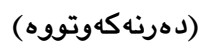

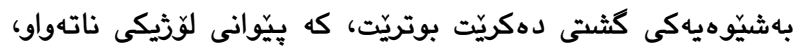
بهوّى ثٔهو ناديارييهيهوهو دهستى هـيه له دروست بوونى كردهى

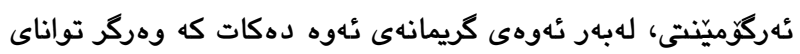

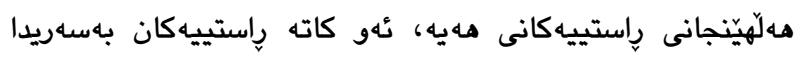
نهسهياون بهلكّو خوّى دواى ليَكدانهوه مهلّى ميّنجاوه.

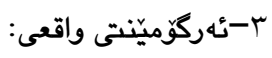

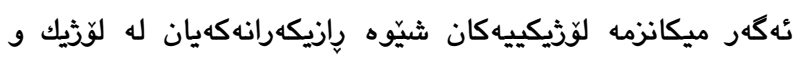

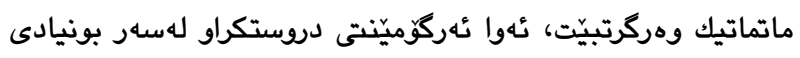
واقع رإزيكهرانه دهبيّت لهبهر هوّكاره واقييهكهى. (صوله ،عبدالله:

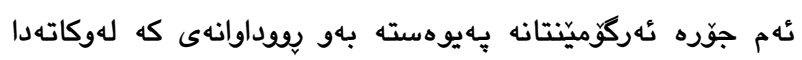

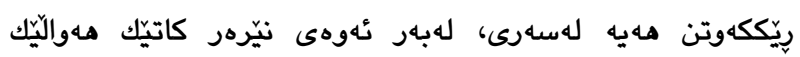
دهخاتهيون، يشت به واقعه دهبهستيّت كهله ئارادايه، ئهو ناجيّت وهسفى ئهو واقعهت بوّ بكات بهشيّوهيهكى تايبهتى بهلكو ئهو رإيانه دهخاته يور كه يِهيوهسته به واقعهوه، لهم بهشانه بِيّك ديّت: ا-ئهركُّميّنته هوَكارييهكان: 
حاتم عبيد ، من الاحتجاج بالعواكف الئ الاحتجاج للعواكف ، جمن الحجاج مفهومه الحه.

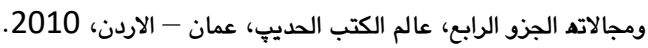

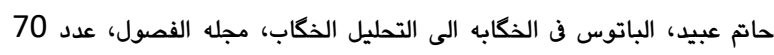
شتاو 2007.

حافث اسماعيل علوى، الحجاج مفهومه ومجالاته، دراسات نثريه وتكبيقيه، في بلاغه الجديده، دار الكتب الحدييو عمان اردن، 2010

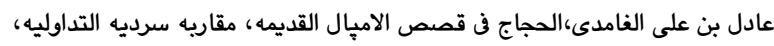
كنوز المعرفه،عمان ، 2016

عبداله صوله ، الحجاج في قران الكريم، من خلال اهم خصائصه الاسلوبيه، ج2، ، دار الفارابى، 2007

عبدالقادر ملوك، حجاجيه الخكاب الاعلامى، اكر نقريه ونمازج تكبيقيه، الرباك، 2018

عبدالله صوله، في نقريه الحجاج،دراسات والتكبيقات،مسكيليانى للنشر والتوزيع،تونس فوله في 2011

عبدالله صوله، كتاب الايام لكه حسين، خكابا الحجياً، احد بحوبٍ ندوه الصناعه

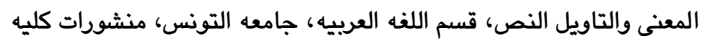
الاداب، المبن والتاويل 1991

محمد مشبال فى بلاغه الحجاج، نحو مقاربه بلاغيه الحجاجيه لتحليل الخكابات ، 1وال

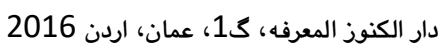

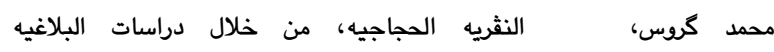

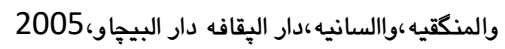

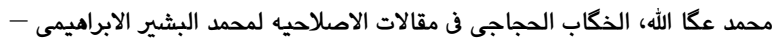

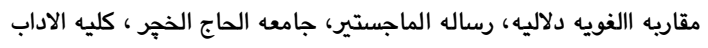
والعلوم الانسانيه ، قسم اللغه وادابها، 2011-2012.

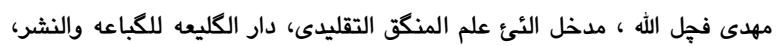
بيروت، 1990

ميشيل ماير ، اللغه والمنكق والحجاج،ترجمه : محمد اسيداه، جهمن الكتاب الحجاج

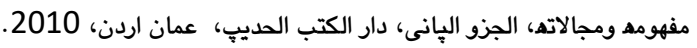

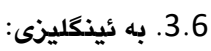

Le grand robert ،dictionnaire de la langue français 1 ،er redaction ‘paris 1989 ،

Longman ‘Dictionary of Contemporary English ، Longman.1989 ،

Cambrige advenced learmers ،dictionary ،Cambrge university press 2 ،nd pub 2004

CH.prrman and L.o. tyteca The new rhetoric a trea ion argumentation ، ،translated by johtn Wilkinson and Purcell wever ،university of Rotterdam 2008

Brandt، ،J.wiliam: the rhetoric of argumentation । st ، printing USA 1970.

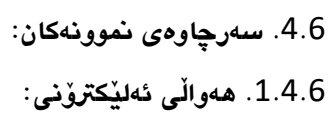

http://speemidia . com/ dreje .as - 19-4-2019

http://speemidia . com/ dreje .as - 19-4-2019

kurdistan 24 official2019-10-2 ،

www.knn.krd-1-7-2019

kurdistan 24 official2019-10-2 ،

kurdistan 24 official2019-7-30،

\section{5ئنجامهكان}

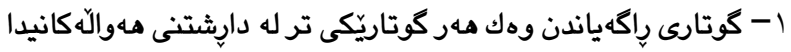

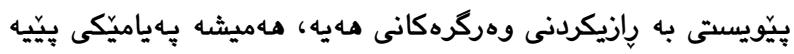

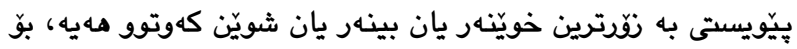
ئهم مهبهسته يهنا بو ميكانزمى جوراو جوّر دهبات له نيّويشياندا ميكانزمه لوَزيكييه كانى ئهركوّمينتت. r- له دارشتنى هـوالدا كاتيّك راستييهكان به بهلكه هينانهوه

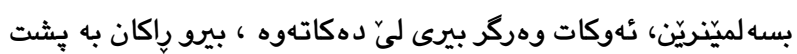

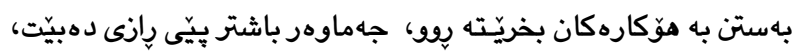

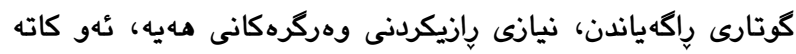
يِيّويستى به جههندين ميكانزمى جوّراو دهبيّت بوّ ئهوهى كوتارهكهى

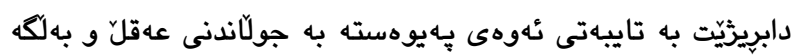
مينانهوهوه.

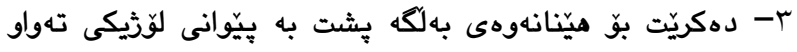

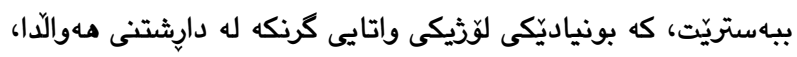

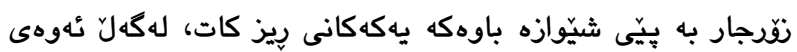
مه ندى جار بهناو دهقهكهدا يهكهكانى دابهش دهبن.

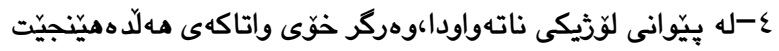
و (استنباگ) دهكات ئهوكاته وهركر به ئهنجامهكه زياتر رازى ده بيّيت و كاريكهرييه كهى لهسهى نِّرتر دهبيّت، لهبهر ئهوهى ئهو ئه نجامهى

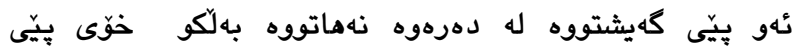
كهيشتووه.

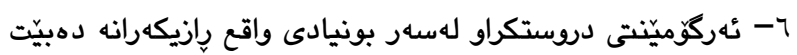
لهبهر هوّكاره واقعييهكهى.

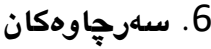

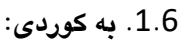

بهكر عومهر عهلى،هِهند لايهيّكى زمانهوانى، له بلّاوكراوهكانى ناوهندى ئاويّر،

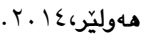

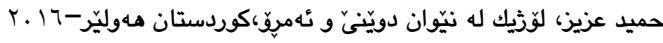

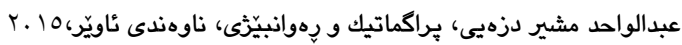

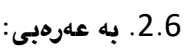

ابن منفور، لسان العرب، دار صادر ، 3 2، لبنان, بيروت,1997.

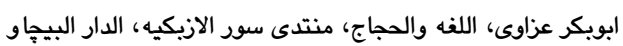

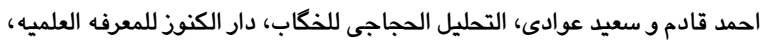

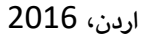
ارسكو، الخكابه ، ترجمه عبدالرحمن البدوى، منشورات دار النون اليقافيه العامه،

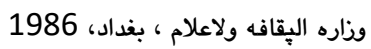

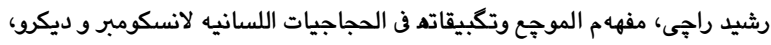
مجله العالم الفكر، عدد2 مجلد 40، اوكتوبر- ديسمبر 2011 


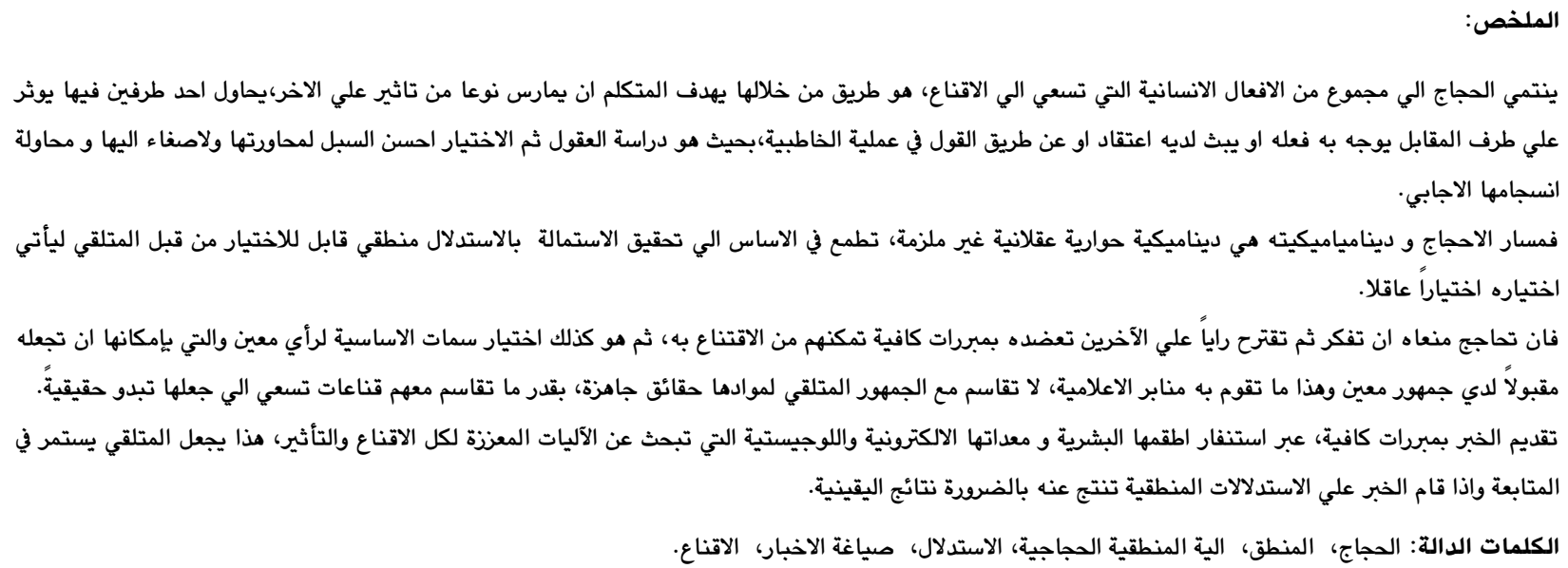

\title{
Logic as argumentation in formulation of news
}

\begin{abstract}
:
Argumentation belongs to a group of human actions that seeks to bring about recipients persuasion rit is a path through which the speaker aims to exert a kind of influence on others 'one of the two parties in it tries to influence the opposite side to direct their actions or broadcast a belief or by saying it in the process of speech. Hence rit is the study of minds c and the best way to dialogue with and listen to it. If you arguing you prevent the recipients from thinking and then proposing an opinion to them rand supporting them with sufficient justifications to enable them to be convinced sthen they also choose the basic features of a certain opinion that can be made acceptable to a specific audience and this is what media platforms do; media does not share ready-made facts with the public as much as it shares with them convictions that sought to make them look like facts. The object reader has decided to read 'so it is our duty to provide it with sufficient justifications to continue to do so rby mobilizing its human teams relectronic and logistical equipment that searches for enhancing mechanisms for influence and persuasion. If the news is based on logical inferences it necessarily results in certainty.
\end{abstract}

Keywords: argumentation -logic - logical argumentation -persuasion - formulation of news, inference. 